\title{
Self-reflective Questioning in Online EFL Speaking Classroom: Framing Oral Skills Through Experiential Learning
}

\author{
Dr. Nasmilah \\ Universitas Hasanuddin, Indonesia \\ imla63@yahoo.com.au
}

\begin{abstract}
This study investigates the effectiveness of self-reflective questioning in improving the EFL learners' speaking skills in online classroom learning. It is meant to respond to the demand of better teaching technique during the pandemic Covid-19 era. This qualitative inquiry involves 16 participants from English Department Hasanuddin University who are taking the subject of Listening and Speaking in their 1st semester. Utilizing questionnaire and semi structure interview, it is revealed that self-reflective questioning representing experiential learning has enriched the learners' active vocabulary as they are encouraged to activate their prior knowledge in order to be able to complete the task. Furthermore, as they must work independently, reinforcement of speech practice develops stronger confidence on the learners' side when talking. These are strengthened by the result of their pre-test and post-test administered in the form of long-distance interview. In contrast to reflective questioning emphasizing group work, self-reflective questioning has shed light on its appropriacy for online speaking classroom, the only alternative platform over the crisis of pandemic Covid-19.
\end{abstract}

Keywords: Self-reflective questioning, online classroom, speaking skills, pandemic Covid-19 